\title{
PERTUMBUHAN, UMUR, DAN MORTALITAS IKAN ENDEMIK BONTI-BONTI (Paratherina striata) DARI DANAU TOWUTI
}

\author{
Syahroma Husni Nasution"1), Ismudi Muschsin'2), Sulistiono2), \\ Dedi Soedharma ${ }^{2}$, dan Soetikno Wirjoatmodjo ${ }^{3)}$ \\ 1) Pusat Penelitian Limnologi-Lembaga Ilmu Pengetahuan Indonesia, Cibinong-Bogor \\ 2) Fakultas Perikanan dan IImu Kelautan-Institut Pertanian Bogor, Bogor \\ 3) Pusat Penelitian Biologi-Lembaga IImu Pengetahuan Indonesia, Cibinong-Bogor \\ Teregristrasi I tanggal: 18 Juli 2007; Diterima setelah perbaikan tanggal: 6 Maret 2008; \\ Disetujui terbit tanggal: 14 Mei 2008
}

\begin{abstract}
ABSTRAK
Ikan bonti-bonti (Paratherina striata) termasuk ke dalam famili Telmatherinidae, bersifat endemik di Danau Towuti dan Danau Mahalona. Ikan ini tergolong rawan punah (vulnerable species). Penurunan stok ikan tersebut dikhawatirkan terjadi di alam, hal tersebut selain karena tingkat eksploitasi yang meningkat juga karena penurunan kualitas habitat. Penelitian ini bertujuan untuk mengkaji parameter pertumbuhan, umur, dan mortalitas ikan bonti-bonti (Paratherina striata) sebagai dasar perumusan dalam pengelolaan. Penelitian ini dilakukan di perairan Danau Towuti. Contoh ikan diperoleh menggunakan jaring insang eksperimental dengan ukuran mata jaring 5/8, 3/4, 1, dan $11 / 4$ inci di 5 stasiun dari bulan Mei 2006 sampai dengan April 2007. Penghitungan pertumbuhan, umur, dan mortalitas ikan dilakukan berdasarkan pada frekuensi ukuran panjang total. Data dianalisis menggunakan soft ware FiSAT II. Hasil penelitian menunjukkan bahwa nilai parameter pertumbuhan pada ikan jantan dan betina masing-masing $L ¥=20,05$ dan $20,45 \mathrm{~cm} ; \mathrm{K}=1,70$ dan 2,00 per tahun; dan to $=-0,02$ dan $-0,01$ tahun. Panjang dan umur ikan jantan dan betina yang tertangkap masing-masing 3,80 sampai dengan $19,78 \mathrm{~cm}$ (0,29 sampai dengan 32,44 bulan) dan 4,68 sampai dengan 18,33 $\mathrm{cm}(0,59$ sampai dengan 8,60 bulan). Ukuran ikan jantan dan betina matang gonad dengan peluang $50 \%$ adalah $16,78 \mathrm{~cm}$ (11,78 bulan) dan $14,61 \mathrm{~cm}$ (5,18 bulan). Terdapat 2 kohort ikan bonti-bonti (Paratherina striata) pada bulan Nopember. Puncak pemijahan diperkirakan terjadi pada bulan Nopember. Laju mortalitas total (Z), laju mortalitas alami (M), dan laju mortalitas karena penangkapan (F) pada ikan jantan dan betina masing-masing 6,32 dan 7,32; 2,89 dan 3,20; dan 3,43 dan 4,12 per tahun. Tingkat pemanfaatan stok ikan bonti-bonti (Paratherina striata) di Danau Towuti ada indikasi kelebihan tangkap baik pada ikan jantan $(E=0,54)$ maupun ikan betina $(E=0,56)$.
\end{abstract}

KATAKUNCI: pertumbuhan, umur, mortalitas, ikan endemik, Paratherina striata, Danau Towuti

ABSTRACT: Growth, age, and mortality of endemic fish bonti-bonti (Paratherina striata) from Lake Towuti. By: Syahroma Husni Nasution, Ismudi Muschsin, Sulistiono, Dedi Soedharma, and Soetikno Wirjoatmodjo

Bonti-bonti (Paratherina striata) that belong to family Telmatherinidae, is an endemic fish species in Lake Towuti and Lake Mahalona. This fish is vulnerable species and its population tend to decrease due to intensive fishing and habitat quality deterioration. This study was aimed to reveal the growth parameters, age, and mortality of bonti-bonti (Paratherina striata) as the foundation for its management. The study was conducted in Lake of Towuti, South Sulawesi. Samples were collected using experimental gill net with mesh sized of 5/8, 3/4, 1, and 1 1/4 inches in five stations from May 2006 to April 2007. Growth, age, and fish mortality were calculated based on total length frequency data using FiSAT II software. Result shows that growth parameters value of male and female $L ¥=20.05$ and $20.45 \mathrm{~cm} ; K=1.70$ and 2.00 per year; and to=-0.02 and -0.01 year, respectively. Length and age of male and female of fish capture were 3.80 to $19.78 \mathrm{~cm}(0.29$ to 32.44 month) and 4.68 to $18.33 \mathrm{~cm}$ (0.59 to 8.60 month). Male and female reached $50 \%$ gonad maturity at the size of $16.78 \mathrm{~cm}(11.78$ month) and $14.61 \mathrm{~cm}$ (5.18 month). There are two cohorts of bonti-bonti (Paratherina striata) in November. The peak spawning season of the fish was predicted occured in November. Total mortality rate, natural mortality rate, and fishing mortality rate of male and female were 6.32 and 7.32; 2.89 and 3.20; and 3.43 and 4.12 per year, respectively. Exploitation level of bonti-bonti (Paratherina striata) stock in Lake Towuti indicate a situation where over fishing (male $E=0.54$ and female $E=0.56$ ) occur.

KEYWORDS: growth, age, mortality, endemic fish, Paratherina striata, and Lake Towuti

Kosrespondensi penulis: 


\section{PENDAHULUAN}

Ikan bonti-bonti (Paratherina striata) yang termasuk ke dalam famili Telmatherinidae adalah ikan endemik dan tergolong rawan punah (vulnerable species) (IUCN, 2003; Froese \& Pauly, 2004). Ikan ini hanya terdapat di Danau Towuti dan Danau Mahalona, Sulawesi Selatan (Kottelat et al., 1993). Masyarakat sekitar Danau Towuti memanfaatkan ikan ini sebagai ikan konsumsi (dalam bentuk ikan segar, kering, atau ikan asin) maupun sebagai ikan hias dan bahan pakan hewan (Nasution, 2006).

Sumber daya ikan bonti-bonti (Paratherina striata) dikhawatirkan mengalami penurunan, selain karena tingkat eksploitasi yang meningkat juga karena kualitas habitat mengalami penurunan. Data akurat seberapa besar tingkat eksploitasi ikan ini belum diperoleh, namun berdasarkan pada hasil wawancara dengan beberapa nelayan di Danau Towuti diketahui bahwa hasil tangkapan dari tahun 2000 sampai dengan 2006 cenderung mengalami penurunan.

Informasi mengenai ikan bonti-bonti (Paratherina striata) terbatas pada sistematika (Weber \& De Beauford, 1922; Kottelat et al. (1993), dan distribusi (Wirjoatmodjo et al., 2003). Namun, ada beberapa penelitian yang dilakukan pada kelompok ikan famili Telmatherinidae jenis lain seperti pada ikan Rainbow selebensis (Telmatherina celebensis) di Danau Towuti mengenai distribusi, morfologi, pertumbuhan, reproduksi, dan kualitas perairan danau tersebut (Nasution \& Sulistiono, 2003; Nasution, 2004; Nasution et al., 2004; Indiarto \& Nasution, 2004; Nasution, 2005a dan b; Nasution et al., 2007; Nasution, 2007). Kebiasaan makanan ikan Rainbow selebensis juga telah diteliti oleh Furkon (2003). Aspek reproduksi ikan opudi ( $T$. antoniae) di Danau Matano dikatakan oleh Sumassetiyadi (2003). Informasi mengenai parameter pertumbuhan, umur, dan mortalitas ikan bonti-bonti (Paratherina striata) belum tersedia.

Beberapa studi telah dilakukan untuk menentukan umur pada beberapa jenis ikan yang didasarkan pada otolit, sisik, atau distribusi panjang (Salekhova, 1979; Tsangridis \& Filippousis, 1988; 1991; 1992). Pada penelitian ini untuk menentukan pertumbuhan, umur dan mortalitas ikan didasarkan pada data frekuensi panjang. Penelitian ini bertujuan untuk mengkaji parameter pertumbuhan, umur, dan mortalitas ikan endemik bonti-bonti (Paratherina striata) dari Danau Towuti. Hal ini, akan bermanfaat dalam pengelolaan perikanan khususnya ikan bonti-bonti (Paratherina striata) di perairan tersebut.

\section{BAHAN DAN METODE}

\section{Tempat dan Waktu Penelitian}

Penelitian dilakukan di perairan Danau Towuti, Kabupaten Luwu Timur, Sulawesi Selatan. Danau Towuti mempunyai luas 560 km2, kedalaman maksimum 203 m, ketinggian dari permukaan laut 293 m, dan transparansi sedalam 22 m (Fernando dalam Haffner et al., 2001). Pengamatan dilakukan setiap bulan secara time series selama 12 bulan dari bulan Mei 2006 sampai dengan April 2007 yang mewakili musim kemarau, hujan, dan peralihan. Pengambilan contoh ikan dan data lingkungan atau habitat dilakukan di setiap pengambilan contoh.

\section{Metode Penelitian}

Metode penelitian yang digunakan adalah metode deskriptif. Desain penelitian dengan cara zonasi (segmentasi) dilakukan dengan mempertimbangkan karakteristik perairan Danau Towuti berdasarkan pada tipologi habitat, dan potensi dampak sawmill dan eksploitasi.

Penentuan stasiun penelitian berdasarkan pada pertimbangan bahwa 1) contoh ikan yang diperoleh akan mewakili ikan bonti-bonti (Paratherina striata) yang ada di Danau Towuti; 2) habitat sesuai bagi ikan tersebut; dan 3) efisiensi operasional pelaksanaan. Berdasarkan pada hal tersebut ditetapkan 5 stasiun penelitian di Danau Towuti (Gambar 1) dan posisi diukur dengan geographic positioning system, sebagai berikut:

1. Stasiun I: Tanjung Bakara, terletak di daerah yang terdapat pengaruh sawmill dan aktivitas penduduk yang tinggi dalam bidang perikanan dengan kedalaman air 1,5 sampai dengan $10 \mathrm{~m}$. Substrat terdiri atas batu, pasir, dan lumpur. Koordinat: $S$ $02^{\circ} 40^{\prime} 47,1^{\prime \prime}-\mathrm{E} 121^{\circ} 25^{\prime} 04,0$ ".

2. Stasiun II: Inlet Danau Towuti yang berasal dari Sungai Tominanga dengan kedalaman air 1 sampai dengan $20 \mathrm{~m}$. Substrat terdiri atas batu, kerikil, dan pasir serta jauh dari tempat tinggal penduduk. Koordinat: S 02³9'43,4"-E 121³2'46,0".

3. Stasiun III: Pulau Loeha, daerah terletak di tengah danau dan tidak dihuni oleh penduduk dengan kedalaman air $>10 \mathrm{~m}$. Substrat terdiri atas batu, kerikil, dan pasir. Koordinat: S 0244'33,9"-E $121^{\circ}$ 34'44,6".

4. Stasiun IV: Outlet Danau Towuti (Sungai Hola-hola) yang mengalir ke Sungai Larona dengan kedalaman air 3 sampai dengan $10 \mathrm{~m}$. Substrat terdiri atas batu dan lumpur, terdapat tanaman air serta jauh dari tempat tinggal penduduk. Koordinat: S 0247'35,1"-E 12124'21,1". 
5. Stasiun V: Beau, terletak di daerah yang terdapat pengaruh aktivitas penduduk yang tinggi dalam bidang perikanan dengan kedalaman air 1,5 sampai dengan $5 \mathrm{~m}$. Substrat terdiri atas lumpur berpasir dan banyak terdapat tanaman air. Koordinat: $S$ 0251'23,2"-E 121'32'46,6".

Contoh ikan bonti-bonti (Paratherina striata) (Gambar 2) diperoleh dari hasil penangkapan menggunakan jaring insang eksperimental dengan 4 ukuran mata jaring yaitu 5/8,3/4, 1, dan 1 1/4 inci dengan panjang masing-masing $50 \mathrm{~m}$ dan tinggi $2 \mathrm{~m}$ sehingga total panjang jaring 1 unit h $200 \mathrm{~m}$. Jaring dilengkapi pelampung pada bagian atas dan pemberat pada bagian bawah. Jaring dipasang dengan sudut 45 sampai degan $90^{\circ}$ terhadap garis pantai.
Pengoperasian jaring dilakukan pada setiap stasiun dari arah pantai ke arah perairan bebas yang dipasang di kolom air bagian atas dari pukul 16.00 sampai dengan 07.00 (Nasution et al., 2007).

Hasil tangkapan dari masing-masing stasiun pengamatan dipisahkan menurut ukuran dan jenis kelamin. Jenis kelamin diketahui dengan melihat tanda seksual primer (gonad) dan seksual sekunder seperti warna tubuh dan keadaan siripa. Jumlah dan ukuran ikan per penarikan alat tangkap selama 15 jam dicatat (Nasution, 2005a). Contoh ikan diawetkan dengan formalin $4 \%$, selanjutnya direndam dalam alkohol $70 \%$. Contoh ikan diukur panjang dan bobot, masing-masing menggunakan jangka sorong dengan ketelitian $1 \mathrm{~mm}$ dan timbangan dengan ketelitian 0,01 g.

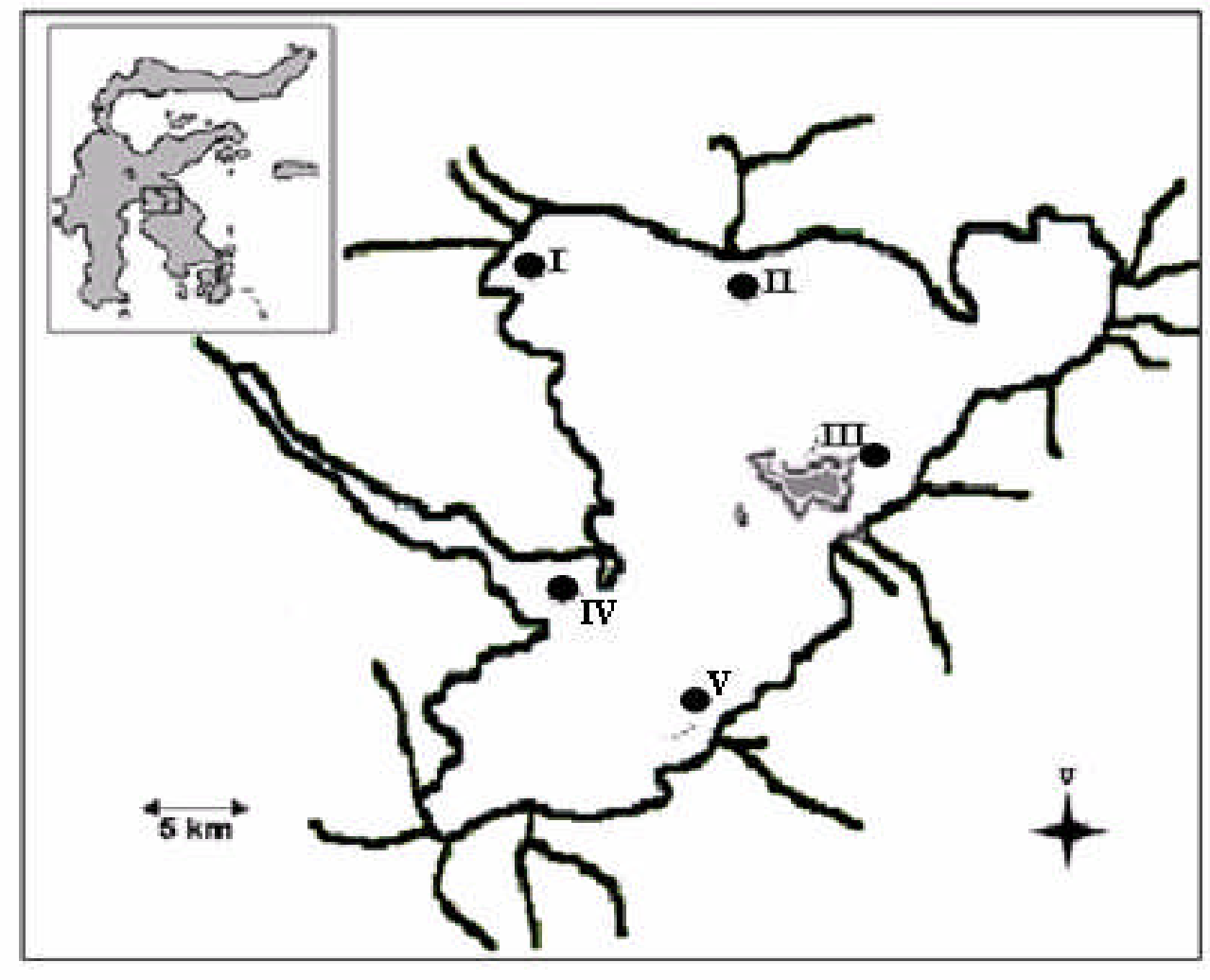

Gambar 1. Stasiun penelitian di Danau Towuti.

Figure 1. Research station in Lake Towuti.

\section{Analisis Data}

\section{Pertumbuhan}

Pola pertumbuhan ikan bonti-bonti (Paratherina striata) diperkirakan dengan menggunakan rumus Von Bertalanffy sebagai berikut:

$\mathrm{L}_{\mathrm{t}}=\mathrm{L}_{\infty}\left[1-\mathrm{e}^{-\mathrm{K}(\mathrm{t}-\mathrm{to})}\right]$ di mana:

$$
\begin{aligned}
& \mathrm{L}_{\mathrm{t}}=\text { panjang ikan pada umur } \mathrm{t}(\mathrm{cm}) \\
& \mathrm{L}_{\infty}=\text { panjang infinity }(\mathrm{cm}) \\
& \mathrm{t}_{0}=\text { umur teoritis ikan pada panjang } 0 \mathrm{~cm} \\
& \mathrm{~K}=\text { koefisien pertumbuhan von Bertalanffy }
\end{aligned}
$$

Parameter pertumbuhan ( $\mathrm{K}$ dan $\mathrm{L}_{\infty}$ ) diduga menggunakan metode ELEFAN I (Spare \& Venema, 
1998; Pauly, 1983), yang terakomodasi pada software FiSAT II.

\section{Umur Teoritis dan Kelompok Umur}

Umur teoritis (to) diduga menggunakan rumus empiris Pauly (1983), berikut ini:

$\log (-$ to) $=-0,3922-0,2752 \log L ¥-1.038 \log K$

dan untuk penentuan kelompok umur dilakukan pemisahan distribusi normal data frekuensi panjang dengan menggunakan metode modal progression analysis Bhattacharya pada soft ware FiSAT II.

\section{Uji Non Parametrik Mann-Whitney}

Perbedaan sebaran data frekuensi panjang ikan jantan dan betina, diuji dengan menggunakan uji non parametrik Mann-Whitney pada soft ware Minitab realese 13.

\section{Mortalitas}

Laju mortalitas total $(Z)$ dalam suatu kegiatan perikanan tangkap sangat penting untuk menganalisis dinamika populasi atau stok ikan. Mortalitas dapat dibedakan dalam mortalitas alami (M) dan mortalitas

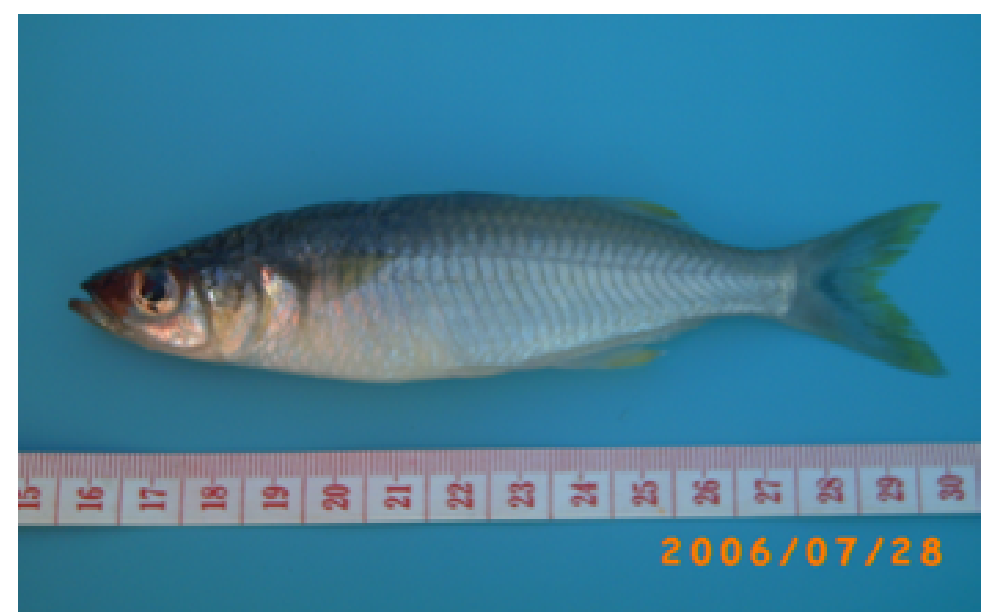

Sumber foto/Photo sources: Nasution (2006)

Gambar 2. Ikan bonti-bonti (Paratherina striata Aurich).

Figure 2. Bonti-bonti (Paratherina striata Aurich).

karena eksploitasi (F). Laju mortalitas total dapat diduga dari pergeseran kelimpahan kelompok umur dan dari analisis kurva hasil tangkapan menggunakan data frekuensi panjang (Spare \& Venema, 1998). Laju mortalitas total dihitung menggunakan rumus:

$\mathrm{Z}=\mathrm{M}+\mathrm{F}$

Laju mortalitas alami (M) diduga dengan metode persamaan empiris Pauly (1983), dengan rumus:

$\log M=-0,0066-0,279 \log L ¥+0,6543 \log K+0,4634$ $\log$

di mana:

$\mathrm{M}=$ mortalitas alami per tahun

$\mathrm{L} ¥ \quad$ = panjang infinity $(\mathrm{cm})$

$\mathrm{K}=$ koefisien pertumbuhan per tahun

$\mathrm{T}$ = suhu rata-rata tahunan $\left({ }^{\circ} \mathrm{C}\right)$

Semua metode tersebut terakomodasi dalam soft ware FiSAT II. Mortalitas karena eksploitasi (F) dapat diperoleh setelah diketahui mortalitas total (Z) dan mortalitas alami (M) dari persamaan $\mathrm{F}=\mathrm{Z}-\mathrm{M}$.

\section{HASIL DAN BAHASAN}

Penghitungan pertumbuhan dan umur ikan di daerah tropis dapat dilakukan berdasarkan pada kelompok ukuran panjang (Sparre \& Venema, 1998). Pada penelitian ini untuk menentukan pertumbuhan, umur, dan mortalitas didasarkan pada kelompok ukuran panjang ikan bonti-bonti (Paratherina striata).

\section{Pertumbuhan}

Berdasarkan pada data panjang ikan bonti-bonti (Paratherina striata) yang tertangkap mulai pada bulan Mei 2006 sampai dengan April 2007 (Tabel 1 dan 2) didapatkan nilai parameter pertumbuhan yaitu pada ikan jantan $L ¥=20,05 \mathrm{~cm} ; K=1,7$ per tahun dan to=0,02 tahun, sedangkan ikan betina $L ¥=20,45 \mathrm{~cm}$; $\mathrm{K}=2,0$ per tahun dan to $=-0,01$ tahun. Kurva fungsi pertumbuhan von Bertalanffy (VBGF) ikan bonti-bonti 
jantan dan betina (Paratherina striata) ditampilkan pada Gambar 3.

Pada ikan bonti-bonti jantan (Paratherina striata), panjang total maximum $19,78 \mathrm{~cm}$ relatif sama dibandingkan dengan panjang infinity $20,05 \mathrm{~cm}$ (Gambar 3), sedangkan panjang maksimal ikan betina yang diperoleh lebih kecil dibandingkan dengan panjang infinity (panjang total maximum $=18,33 \mathrm{~cm}$ dan panjang infinity $=20,45 \mathrm{~cm}$ ). Perbedaan antara panjang maksimal yang diperoleh dengan panjang infinity pada ikan betina, menimbulkan penafsiran bahwa ada ikan berukuran lebih besar dari $18,33 \mathrm{~cm}$ yang tidak tertangkap. Sparre \& Venema (1998) menyarankan dilakukan perbandingan dengan metode lain (sisik dan otolit) untuk memastikan.

Pada ikan Rainbow selebensis panjang infinity adalah $11,90 \mathrm{~cm}$, sedangkan panjang maksimal ikan jantan dan ikan betina masing-masing 10,32 cm dan $9,46 \mathrm{~cm}$ (Nasution, 2007). Ikan Rainbow selebensis dan ikan bonti-bonti (Paratherina striata) adalah ikan endemik yang kelimpahan paling tinggi $(37,8 \%$ dan $41,7 \%)$ pada kelompok famili Telmatherinidae di Danau Towuti (Wirjoatmodjo et al., 2003; Nasution, 2004). Demikian juga, dengan ukuran tubuh ikan bontibonti (Paratherina striata) paling besar dibandingkan ikan satu famili yang terdapat di danau tersebut.
Laju pertumbuhan ikan bonti-bonti betina (Paratherina striata) ( $\mathrm{K}=2,0$ per tahun) relatif lebih tinggi dibandingkan ikan jantan ( $K=1,7$ per tahun). Hal ini, mengatakan bahwa makin besar nilai $\mathrm{K}$, maka makin cepat $L ¥$ didekati atau dicapai, atau makin pendek umur ikan. Ukuran rata-rata ikan jantan dan ikan betina yang tertangkap tidak berbeda nyata (Tabel 3).

\section{Umur}

Umur ikan bonti-bonti (Paratherina striata) pada panjang tertentu dapat ditentukan berdasarkan pada rumus pertumbuhan. Panjang ikan bonti-bonti jantan dan betina (Paratherina striata) pada umur t yaitu $\mathrm{Lt}=20,05[1-\mathrm{e}-1,70 .(\mathrm{t}+0,02)]$ dan $\mathrm{Lt}=20,45[1-\mathrm{e}-$ $2,00$. $(t+0,01)]$. Penentuan umur sangat penting antara lain berkaitan dengan pendugaan rekruitmen (penambahan baru) ikan. Perkiraan umur ikan bontibonti jantan dan betina (Paratherina striata) dapat dilihat pada Tabel 4. Umur rata-rata ikan yang tertangkap berumur 3 bulan lebih (jantan berumur 4 bulan 18 hari dan betina berumur 3 bulan 19 hari), sedangkan umur ikan bonti-bonti jantan dan betina (Paratherina striata) dengan peluang $50 \%$ matang gonad (siap memijah), masing-masing 12 bulan 17 hari dan 5 bulan 5 hari.

Tabel 1. Sebaran data frekuensi panjang ikan bonti-bonti jantan (Paratherina striata) Table 1. Distribution of length frequency data of male bonti-bonti (Paratherina striata)

\begin{tabular}{|c|c|c|c|c|c|c|c|c|c|c|c|c|c|}
\hline \multirow{2}{*}{$\begin{array}{c}\text { Kelas } \\
\text { ukuran/ } \\
\text { Range } \\
\text { class } \\
\text { (cm) }\end{array}$} & \multicolumn{12}{|c|}{ Waktu pengambilan contoh/Time of take sample } & \multirow{2}{*}{$\begin{array}{c}\text { Jumlah/ } \\
\text { Total }\end{array}$} \\
\hline & M-6 & $\mathrm{J}-6$ & $\mathrm{~J}-6$ & A-6 & S-6 & $0-6$ & N-6 & D-6 & J-7 & $F-7$ & $M-7$ & A-7 & \\
\hline 1 & 0 & 0 & 0 & 0 & 0 & 0 & 0 & 0 & 0 & 0 & 0 & 0 & 0 \\
\hline 3 & 0 & 0 & 0 & 0 & 0 & 0 & 1 & 0 & 0 & 0 & 0 & 0 & 1 \\
\hline 5 & 0 & 0 & 0 & 0 & 0 & 0 & 14 & 22 & 0 & 15 & 0 & 3 & 54 \\
\hline 7 & 3 & 2 & 12 & 0 & 0 & 0 & 95 & 57 & 4 & 1 & 1 & 9 & 184 \\
\hline 9 & 19 & 0 & 6 & 0 & 8 & 1 & 72 & 64 & 1 & 2 & 3 & 13 & 189 \\
\hline 11 & 25 & 1 & 11 & 12 & 12 & 8 & 25 & 14 & 5 & 6 & 14 & 28 & 161 \\
\hline 13 & 11 & 9 & 7 & 17 & 15 & 15 & 19 & 3 & 3 & 15 & 12 & 44 & 170 \\
\hline 15 & 7 & 3 & 1 & 5 & 27 & 6 & 11 & 3 & 4 & 11 & 0 & 21 & 99 \\
\hline 17 & 0 & 1 & 0 & 1 & 6 & 2 & 3 & 1 & 0 & 2 & 0 & 3 & 19 \\
\hline 19 & 0 & 0 & 0 & 0 & 2 & 0 & 0 & 0 & 0 & 0 & 0 & 0 & 2 \\
\hline $\begin{array}{c}\text { Jumlah/ } \\
\text { Total }\end{array}$ & 65 & 16 & 37 & 35 & 70 & 32 & 240 & 164 & 17 & 52 & 30 & 121 & 879 \\
\hline
\end{tabular}

Keterangan/Remarks:M-6 = Mei 2006; J-6 = Juni 2006; J-6 =;Juli 2006; A-6 = Agustus 2006; S-6 = September 2006; O-6 = Oktober 2006; N-6 = Nopember 2006; D-6 = Desember 2006; J-7 = Januari 2007; F-7 = Pebruari 2007; M-7 = Maret 2007; A-7 = April 2007 
Tabel 2. Sebaran data frekuensi panjang ikan bonti-bonti betina (Paratherina striata)

Table 2. Distribution of length frequency data of female bonti-bonti (Paratherina striata

\begin{tabular}{|c|c|c|c|c|c|c|c|c|c|c|c|c|c|}
\hline \multirow{2}{*}{$\begin{array}{c}\text { Kelas } \\
\text { ukuran/ } \\
\text { Range } \\
\text { class } \\
(\mathrm{cm})\end{array}$} & \multicolumn{12}{|c|}{ Waktu pengambilan contoh/Time of take sample } & \multirow{2}{*}{$\begin{array}{c}\text { Jumlah } \\
\text { Total }\end{array}$} \\
\hline & M-6 & $\mathrm{J}-6$ & J-6 & A-6 & S-6 & $0-6$ & N-6 & D-6 & J-7 & F-7 & M-7 & A-7 & \\
\hline 1 & 0 & 0 & 0 & 0 & 0 & 0 & 1 & 0 & 0 & 0 & 0 & 0 & 1 \\
\hline 3 & 0 & 0 & 0 & 0 & 0 & 0 & 0 & 0 & 0 & 0 & 0 & 0 & 0 \\
\hline 5 & 2 & 0 & 0 & 0 & 0 & 0 & 5 & 21 & 0 & 11 & 0 & 5 & 44 \\
\hline 7 & 0 & 2 & 7 & 0 & 0 & 0 & 106 & 107 & 2 & 13 & 0 & 9 & 247 \\
\hline 9 & 9 & 1 & 4 & 1 & 0 & 3 & 65 & 68 & 2 & 6 & 2 & 22 & 182 \\
\hline 11 & 11 & 2 & 12 & 23 & 5 & 8 & 18 & 17 & 1 & 23 & 16 & 22 & 158 \\
\hline 13 & 10 & 1 & 10 & 21 & 11 & 17 & 17 & 12 & 1 & 10 & 5 & 6 & 121 \\
\hline 15 & 5 & 1 & 6 & 7 & 6 & 4 & 2 & 3 & 0 & 1 & 0 & 3 & 38 \\
\hline 17 & 0 & 0 & 0 & 0 & 0 & 0 & 0 & 0 & 0 & 0 & 0 & 0 & 0 \\
\hline 19 & 0 & 0 & 0 & 0 & 0 & 0 & 0 & 0 & 0 & 0 & 0 & 0 & 0 \\
\hline $\begin{array}{c}\text { Jumlah/ } \\
\text { Total }\end{array}$ & 37 & 7 & 39 & 52 & 22 & 32 & 214 & 228 & 6 & 64 & 23 & 67 & 791 \\
\hline
\end{tabular}

Keterangan/Remarks:M-6 = Mei 2006; J-6 = Juni 2006; J-6 = Juli 2006; A-6 = Agustus 2006; S-6 = September 2006; O-6 = Oktober 2006; N-6 = Nopember 2006; D-6 = Desember 2006; J-7 = Januari 2007; F-7 = Pebruari 2007; M-7 = Maret $2007 ;$ A-7 = April 2007

Male

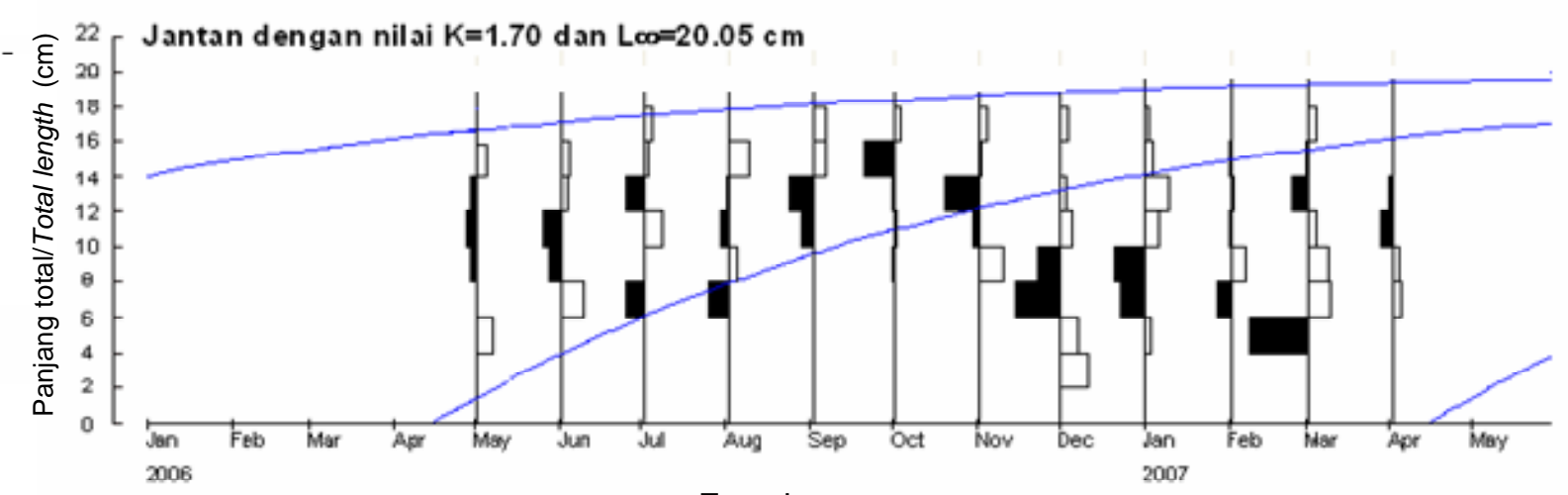

Female

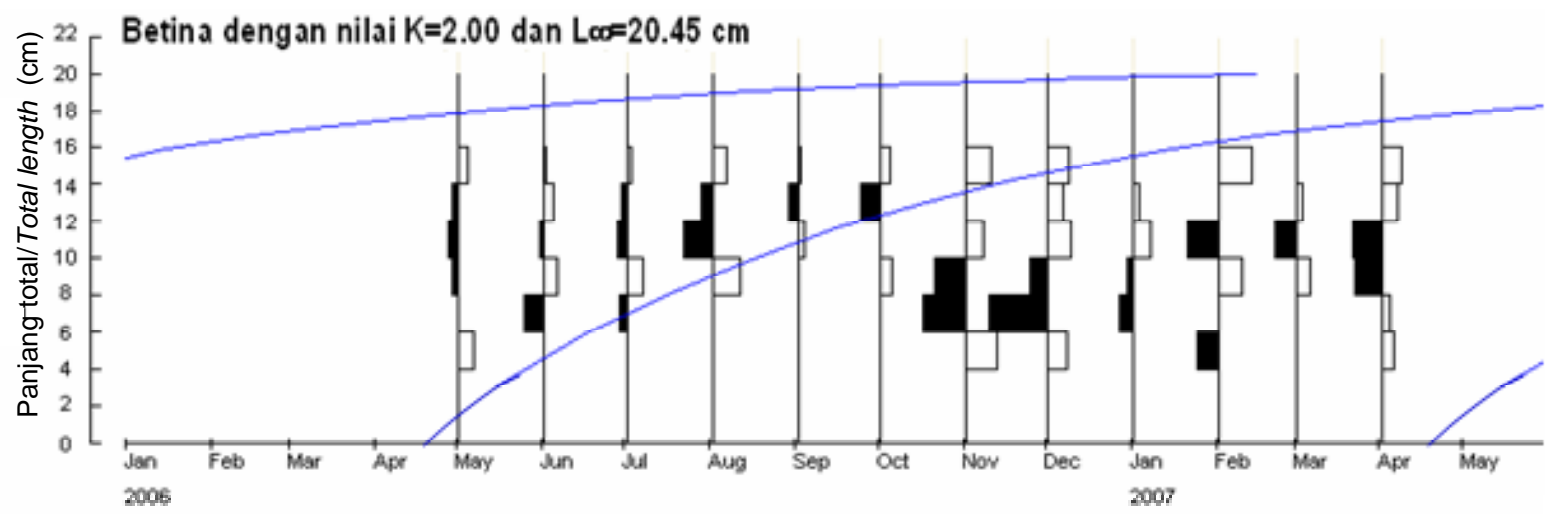

Gambar 3. Kurva pertumbuhan von Bertalanffy berdasarkan pada data frekuensi panjang ikan bontibonti jantan dan betina (Paratherina striata).

Figure 3. Von Bertalanffy growth curve of male and female bonti-bonti fish (Paratherina striata) based on length frequency data. 
Pada bulan Nopember sebaran frekuensi panjang ikan bonti-bonti (Paratherina striata) tampak mempunyai 2 puncak kurva yang diduga sebagai kohort. Berdasarkan pada sebaran data pada bulan tersebut (Tabel 1 dan 2), dilakukan pemisahan distribusi normal data dan hasil menunjukkan terdapat 2 kelompok umur ikan (kohort) yang ditampilkan pada Gambar 4.

Diperkirakan umur ikan bonti-bonti jantan (Paratherina striata) pada puncak kohort I dan II di bulan Nopember masing-masing panjang $5 \mathrm{~cm}=1,71$ bulan dan panjang $12 \mathrm{~cm}=6,20$ bulan, sedangkan pada ikan betina panjang $7 \mathrm{~cm}=2,39$ bulan dan panjang $11 \mathrm{~cm}=4,51$ bulan. Berdasarkan pada umur ikan pada kohort tersebut dapat diperkirakan musim pemijahan ikan. Musim pemijahan ikan yang menghasilkan kohort ikan dewasa (II) diperkirakan dengan menghitung mundur 5 sampai dengan 6 bulan dari bulan Nopember, yaitu terjadi sekitar bulan Juni sampai dengan Juli, baik pada ikan jantan maupun ikan betina.

Musim pemijahan ikan yang menghasilkan rekruitmen atau penambahan kelompok ikan baru (kohort muda atau I) diperkirakan dengan menghitung mundur 1 sampai dengan 2 bulan dari bulan Nopember yaitu terjadi sekitar bulan Oktober-Nopember. Patut diduga bahwa bulan Nopember merupakan puncak pemijahan ikan bonti-bonti (Paratherina striata) karena menghasilkan kelimpahan paling tinggi dibandingkan bulan lain. Nasution (2005a) mengatakan bahwa pada bulan Nopember juga merupakan puncak pemijahan ikan Rainbow selebensis.

Tabel 4. Panjang dan umur ikan bonti-bonti (Paratherina striata) yang tertangkap di Danau Towuti Table 4. $\quad$ Length and age of bonti-bonti fish (Paratherina striata) capture in Lake Towuti

\begin{tabular}{llccccc}
\hline Jenis kelamin/Sex & $\begin{array}{c}\text { Minimal/ } \\
\text { Minimal }\end{array}$ & $\begin{array}{c}\text { Rata-rata/ } \\
\text { Mean }\end{array}$ & $\begin{array}{c}\text { Matang } \\
\text { gonad/Gonad } \\
\text { maturity 50\% }\end{array}$ & $\begin{array}{c}\text { Maksimal/ } \\
\text { Maximal }\end{array}$ & Infinity \\
\hline \multirow{2}{*}{ Jantan } & Panjang (cm) & 3,80 & 9,93 & 16,78 & 19,78 & 20,05 \\
& Umur (bulan) & 1,24 & 4,59 & 12,56 & 30,17 & $>53,43$ \\
\multirow{2}{*}{ Betina } & Panjang (cm) & 4,68 & 9,49 & 14,61 & 18,33 & 20,45 \\
& Umur (bulan) & 1,44 & 3,62 & 5,18 & 13,48 & $>45,62$ \\
\hline
\end{tabular}

\section{Mortalitas}

Laju mortalitas total (Z) ikan bonti-bonti jantan dan betina (Paratherina striata) masing-masing 6,32 dan 7,32 per tahun. Laju mortalitas alami (M) ikan jantan dan betina ditentukan dengan rumus Pauly yang memerlukan data $\mathrm{L} ¥ \mathrm{~K}$, dan suhu rata-rata tahunan $\left(29,4^{\circ} \mathrm{C}\right)$, maka diperoleh nilai M masing-masing 2,89 dan 3,20 per tahun. Nilai F (laju mortalitas karena penangkapan) pada ikan jantan dan betina yang diperoleh dari kurva panjang hasil tangkapan yang dikonversi (Gambar 5) masing-masing 3,43 dan 4,12 per tahun. Dari hasil ini terlihat bahwa laju mortalitas karena penangkapan baik pada ikan bonti-bonti jantan maupun betina (Paratherina striata) lebih besar dibandingkan dengan laju mortalitas alami.

Beverton \& Holt (1966), memastikan mortalitas alami (M) dan membandingkan dengan laju pertumbuhan (K). Nisbah $\mathrm{M} / \mathrm{K}$ pada umumnya kebanyakan ikan berkisar antara 1,12 sampai dengan 2,50. Pada kasus perikanan yang tangkap lebih di Danau Volta Ghana, nisbah M/K meningkat dari 1,66 menjadi 2,02 (Ofori et al., 2001). Peningkatan nisbah tersebut disebabkan oleh menurunnya nilai $\mathrm{K}$ akibat ada tekanan penangkapan. Pada ikan bonti-bonti jantan dan betina (Paratherina striata), nisbah $\mathrm{M} / \mathrm{K}$ 1,70 dan 1,60. Nisbah M/K lebih rendah pada ikan betina, namun perbedaan nilai tersebut relatif kecil. Perbedaan nisbah $\mathrm{M} / \mathrm{K}$ tersebut disebabkan oleh laju pertumbuhan ikan betina (2,0 per tahun) lebih cepat dibandingkan ikan jantan (1,7 per tahun).

Berdasarkan pada mortalitas alami (M) dan mortalitas karena penangkapan $(F)$ ikan bonti-bonti jantan dan betina (Paratherina striata) tersebut, dapat ditentukan laju eksploitasi $(E)$ yang dihitung dengan rumus $E=F / Z$. Laju eksploitasi merupakan indeks yang menggambarkan tingkat pemanfaatan stok di suatu perairan. Sparre \& Venema (1998) mengatakan nilai $E=0,50$ menunjukkan tingkat pemanfaatan stok maksimal dan $E>0,50$ menunjukkan tingkat pemanfaatan stok sudah lebih tangkap (over exploitation). Tingkat pemanfaatan stok ikan bontibonti (Paratherina striata) di Danau Towuti ada indikasi kelebihan tangkap baik pada ikan jantan maupun betina $(E=0,54$ dan $E=0,56)$. 

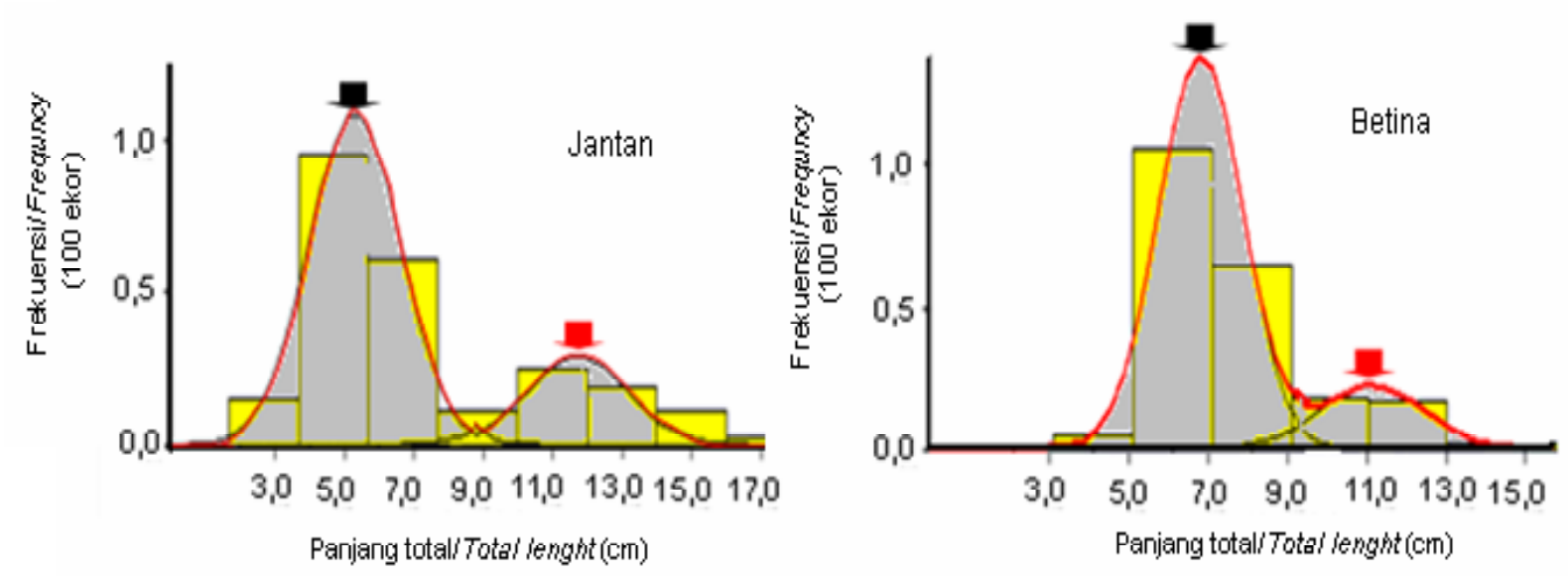

Gambar4. Analisis Bhattacharya pada sebaran frekuensi panjang ikan bonti-bonti (Paratherina striata) bulan Nopember kohort I dan $\Omega^{\text {kohort II). }}$

Figure 4. Bhattacharya analysis on length frequency distribution of bonti-bonti in (Paratherina striata) Nopember ( kohort I and ¿kohort II).


Gambar 5. Mortalitas ikan bonti-bonti jantan dan betina (Paratherina striata) berdasarkan pada kurva panjang hasil tangkapan yang dikonversi.

Figure 5. Mortality of male and female bonti-bonti (Paratherina striata) based on length converted catch curve.

Penelitian tentang potensi ikan di Danau Towuti sangat sedikit, terlebih lagi kajian mengenai stok. Ikan bonti-bonti (Paratherina striata) pada umumnya tertangkap oleh nelayan bagan. Samuel et al. (2005) mengatakan dari 203,9 ton hasil penangkapan di Danau Towuti pada tahun 2004, bagan menyumbang 137,4 ton $(67,4 \%)$. Kelemahan alat tangkap bagan tidak selektif karena ikan yang tertangkap dari ukuran kecil sampai dengan besar.
Tingkat pengoperasian bagan diduga ada hubungan dengan laju ekploitasi yang dihasilkan dari perhitungan tersebut $(E=0,54$ dan $E=0,56)$. Jumlah bagan yang beroperasi meningkat secara signifikan. Menurut Samuel et al. (2005), jumlah alat tangkap terutama bagan yang beroperasi di perairan Danau Towuti pada tahun 2003 hanya berjumlah 4 buah, meningkat menjadi 15 buah pada tahun 2005. Berdasarkan pada pengamatan langsung tahun 2006, 
jumlah bagan sudah mencapai 19 buah. Peningkatan alat tangkap tersebut disinyalir akan menurunkan populasi ikan bonti-bonti (Paratherina striata).

\section{KESIMPULAN}

1. Laju pertumbuhan tahunan ikan bonti-bonti betina (Paratherina striata) $(\mathrm{K}=2,0$ per tahun) relatif lebih cepat dibandingkan dengan ikan jantan ( $\mathrm{K}=1,7$ per tahun).

2. Panjang dan umur ikan bonti-bonti jantan dan betina (Paratherina striata) yang tertangkap masing-masing 3,80 sampai dengan $19,78 \mathrm{~cm}$ atau 1,24 sampai dengan 30,17 bulan dan 4,68 sampai dengan 18,33 cm atau 1,44 sampai dengan 13,48 bulan, sedangkan ikan jantan dan betina matang gonad dengan peluang $50 \%$ dicapai pada ukuran $16,78 \mathrm{~cm}$ (12,56 bulan) dan $14,61 \mathrm{~cm}$ (5,18 bulan).

3. Pada bulan Nopember terdapat 2 kohort ikan bontibonti (Paratherina striata) yang diduga berasal dari musim pemijahan bulan Juni sampai dengan Juli dan bulan Oktober sampai dengan Nopember. Puncak pemijahan diperkiran terjadi pada bulan Nopember.

4. Laju mortalitas total (Z) ikan bonti-bonti jantan dan betina (Paratherina striata) 6,32 dan 7,32 per tahun, mortalitas alami (M) masing-masing 2,89 dan 3,20 per tahun, dan mortalitas karena penangkapan ( $F$ ) masing-masing 3,43 dan 4,12 per tahun. Laju eksploitasi (E) ikan bonti-bonti (Paratherina striata) di Danau Towuti ada indikasi kelebihan tangkap pada ikan jantan dan betina (Paratherina striata) $(\mathrm{E}=0,54$ dan $\mathrm{E}=0,56)$.

5. Dalam upaya pengelolaan sumber daya perikanan (khususnya stok ikan bonti-bonti (Paratherina striata) di Danau Towuti perlu segera dilakukan pembatasan jumlah alat tangkap, khususnya bagan dan waktu penangkapan pada bulan Nopember (puncak musim pemijahan).

\section{UCAPAN TERIMA KASIH}

Penulis mengucapkan terima kasih pada PT. INCO Sorowako, Sulawesi Selatan yang telah membantu dalam penyediaan data sekunder serta dana untuk analisis data. Juga terima kasih pada Bapak Drs. Jefry Jack Mamangkey, M.Si.; Dista Setiana; dan Siti Aminah yang telah membantu selama penelitian. Pada Bapak Dr. Ir. Dede Irving Hartoto, APU yang telah memberikan artikel-artikel dan masukan yang berkaitan dengan penelitian ini. Segenap Staf di Pusat Penelitian Limnolog-Lembaga IImu Pengetahuan Indonesia atas bantuan dan dukungan yang diberikan. Pihak-pihak lain atas bantuan dan masukan yang sangat berarti bagi Penulis.

\section{PERSANTUNAN}

Kegiatan ini terselenggara atas bantuan PT. INCO, tahun 2006-2007

\section{DAFTAR PUSTAKA}

Beverton, R. H. J. \& S. J. Holt. 1966. Manual of methods of fish stock assessment. Part II. Tables of Yield fuction. FAO Fish. Tech. Pap. 38 (Rev-1). $67 \mathrm{p}$.

Froese, R. \& D. Pauly. Editors. 2004. Fish base. World Wide Web electronic publication. www.fishbase.org. Download on July 6, 2004.

Furkon, A. 2003. Kebiasaan makanan ikan bonti (Telmatherina celebensis) di Danau Towuti, Sulawesi Selatan. Fakultas Perikanan dan IImu Kelautan Institut Pertanian Bogor. Bogor. 41 hal.

Haffner, G. D., P. E. Hehanussa, \& D. I. Hartoto. 2001. The biology and physical processes of large lakes of Indonesia: Lakes Matano and Towuti. In M. Munawar \& R. E. Hecky (eds.). The Great Lakes of the World: Food-Web, Health, and Integrity. Netherlands. p. 183-192.

Indiarto, Y. \& S. H. Nasution. 2004. Makrofita air Ottelia mesenterium dalam kaitannya dengan kelimpahan ikan Rainbow selebensis (Telmatherina celebensis) di Danau Towuti. LIMNOTEK Perairan Darat Tropis di Indonesia. XI (2). 45-49.

IUCN. 2003. IUCN Redlist of threatened species www.redlist.org. Download on July 16, 2004.

Kottelat, M., A. J. Whitten, S. N. Kartikasari, \& S. Wirjoatmodjo. 1993. Ikan air tawar Indonesia bagian Barat dan Sulawesi. Periplus Edition (HK) Ltd. Bekerjasama dengan Proyek EMDI. Kantor Menteri Negara Kependudukan dan Lingkungan Hidup Republik Indonesia. Jakarta. $293 \mathrm{hlm}$.

Nasution, S. H. \& Sulistiono. 2003. Kematangan gonad ikan endemik Rainbow selebensis 
(Telmatherina celebensis Boulenger) di Danau Towuti. Jurnal IImu-IImu Perairan dan Perikanan Indonesia. 10 (2). 71-77.

Nasution, S. H., Sulistiono, D. S. Sjafei, \& G. S. Haryani. 2004. Variasi morfologi ikan endemik Rainbow selebensis (Telmatherina celebensis Boulenger) di Danau Towuti, Sulawesi Selatan. Jurnal Akuakultur Indonesia. 3 (2). 13-18.

Nasution, S. H. 2004. Conservation of endemic fish Telmatherina celebensis in Lake Towuti, South Celebes. Proceedings of the International Workshop on Human Dimension of Tropical Peatland Under Global Environmental Changes. December 8-9, 2004. Bogor-Indonesia. Supported by Japan Society for the Promotion of Science. The Indonesian Institute of Sciences, and University of Palangkaraya. p 35-42.

Nasution, S. H. 2005a. Karakteristik reproduksi ikan endemik Rainbow selebensis (Telmatherina celebensis Boulenger) di Danau Towuti. Jurnal Penelitian Perikanan Indonesia. Edisi Sumber Daya dan Penangkapan. 11 (2). 29-37.

Nasution, S. H. 2005b. Karakteristik habitat, aspek biologi, dan upaya pengelolaan ikan endemik Telmatherina celebensis di Danau Towuti. Makalah Seminar Pertemuan Pakar Perikanan. Badan Riset Kelautan dan Perikanan. Pusat Riset Perikanan Tangkap. 02 Agustus 2005. Jakarta. Hal. 8-1-8-26.

Nasution, S. H. 2006. Pangkilang (Telmatherinidae) ornamental fish: An economic alternative for people around Lake Towuti. Proceedings International Symposium on the Ecology and Limnology of the Malili Lakes on March 20-22, 2006 in BogorIndonesia. p 39-46.

Nasution, S. H., Sulistiono, D. S. Sjafei, \& G. S. Haryani. 2007. Distribusi spasial dan temporal ikan endemik Rainbow selebensis (Telmatherina celebensis Boulenger) di Danau Towuti, Sulawesi Selatan. Jurnal Penelitian Perikanan Indonesia. Edisi Sumber Daya dan Penangkapan. 13 (2). 95104.

Nasution, S. H. 2007. Growth and condition factor of Rainbow selebensis (Telmatherina celebensis Boulenger) in Lake Towuti, South Celebes. Indonesian Fisheries Research Journal. 13. (2). 117-123.

Ofori, P. K., C. J. Vanderpuye, \& G. J. de Graaf Nefisco. 2001. Growth and mortality of the catfish (Hemisynodontis membranaceus), in the northern arm of Lake Volta, Ghana. Fisheries Management and Ecology. 8. 37-45.

Pauly, D. 1983. Some simple method for assessment to tropical stock. FAO Fish Tech. Paper. 242. 52 p.

Salekhova, L. P. 1979. Centracanthidae fishes of the genus Spicara from the Mediterranean and Black Sea. Haykova-Dumka, Kiev.172 p.

Samuel, Z. Fahmi, \& S. Gautama. 2005. Riset keanekaragaman hayati dan bahan rumusan pengelolaan jenis ikan endemik perairan pedalaman di Sulawesi. Laporan Perjalanan Dinas. Pusat Riset Perikanan Tangkap. Badan Riset Kelautan dan Perikanan. Departemen Kelautan dan Perikanan. 19 hal.

Sparre, P. \& S. C. Venema. 1998. Introduksi pengkajian stok ikan tropis. Badan Penelitian dan pengembangan Perikanan. Terjemahan dari Introduction to Tropical fish stock assessment. FAO Fish Tech. Paper. 306. (1). 376 p.

Sumassetiyadi, M. A. 2003. Beberapa aspek reproduksi ikan opudi (Telmatherina antoniae) di Danau Matano Sulawesi Selatan. Fakultas Perikanan dan IImu Kelautan Institut Pertanian Bogor. Bogor. 56 hal.

Tsangridis, A. \& Filippousis, N. 1988. Lengthbased approach to the estimation of growth and mortality parameters of Spicara smaris (L.) in the Saronikos Gulf, Greece, and remarks on the application of the Beverton and Holt relative yield per recruit model. FAO Fish. Rep. 412. 94-107.

Tsangridis, A. \& Filippousis, N. 1991. Use of length frequency data in the estimation of growth parameters of three Mediterranean fish species: Bogue (Boops boops L.), picarel (Spicara smaris L.) and horse mackerel (Trachurus trachurus L.). Fisheries Resources. 12. 283-297.

Tsangridis, A. \& Filippousis, N. 1992. Growthpattern of picarel Spicara smaris (L.) (Centracanthidae), a protognyous species. Cybium. 3. 233-243.

Weber, M. \& De Beaufort. 1922. The fishes of the Indo Australian Archipelago. Vol.IV. E. J. Brill. Leiden. $235 \mathrm{p}$.

Wirjoatmodjo, S., Sulistiono, M. F. Rahardjo, I. S. Suwelo, \& R. K. Hadiyati. 2003. Ecological distribution of endemic fish species in Lakes Poso and Malili Complex, Sulawesi Island. Funded by Asean Regional Centre for Biodiversity Conservation and the European Comission. 30 p. 